\title{
Venstre om i Latinamerika
}

\section{Niels Lindvig}

\section{Latinamerika er uden tvivl trådt mod venstre i de senere år, men den generelle orientering i politik- ken er ikke entydig bortset fra det geopolitiske faktum, at de fleste sigter på større økonomisk og politisk uafhængighed af USA}

Den politiske venstredrejning i Latinamerika har i de senere år optaget sindene hos iagttagere af regionen, og fokus er især på forholdet til USA, som er blevet mere anstrengt. Ikke fordi nogle lande har ønsket at forringe forholdet til Washington, men fordi USA i en række tilfælde har reageret afvisende på et ønske om større albuerum politisk og økonomisk. Et ønske om større selvstændighed. Med Hugo Chavez' valgsejr i Venezuela i 1998 og med Lula da Silvas valgsejr i Brasilien i 2002 blev den internationale opmærksomhed omkring tendensen i retning af en venstreorientering skærpet.

Under den brasilianske valgkamp i 2002 advarede USA's finansminister, Paul O'Neill, om, at man måtte være forsigtig med at låne Brasilien penge med udsigt til en Lula-regering til venstre for midten. "Først må vi se en politik, som sikrer, at pengene bliver brugt til noget godt og ikke bare forsvinder ud af landet til en bankkonto i Schweiz", sagde finansministeren fra Washington, og afslørede dermed også de fordomme, som man havde mod socialisten Lula da Silva.

Det værste var dog, at den ene udtalelse fra Paul O'Neill øjeblikkeligt høvlede 5 procent af den brasilianske valutas værdi. Den brasilianske real mistede i løbet af 2002 en tredjedel af sin værdi alene på grund af gentagne udenlandske skrækscenarier om Lula da Silva.

De toneangivende finansaviser, Wall Street Journal og Financial Times, var på samme linje og advarede i en række artikler investorerne i Brasilien imod Lula med det resultat, at investorerne flygtede ud af Brasilien i stor stil op til præsidentvalget. Præsident Lula da Silva har senere beteg- 
net de to avisers skriverier som 'finansiel terrorisme'.

Ingen - hverken presse eller medier eller USA's regering - har efterfølgende indrømmet, at de eklatant fejlvurderede situationen og især manden Lula. Og så vidt som beklagelser kom det aldrig. Som venstreorienteret har man selv pligt til at gøre fordommene til skamme og bevise sin lødighed.

\section{De gode og de onde}

Det varede ikke længe, før det hele var vendt på hovedet. Lula da Silva var pludselig den helt store attraktion. Efterspurgt ved topmøder verden over, modtaget som en konge i Davos af sine gamle kritikere, som lyttede i en blanding af andægtighed og begejstring til, hvad den brasilianske præsident havde at sige. Og alligevel var der det her indtryk af markedspladstelt, hvor man kunne opleve sensationen: den velafrettede vilde.

Der gik ikke lang tid, før det blev god latin at tale - ikke om venstredrejningen i Latinamerika, men om venstredrejningerne. Blandt andre Mexicos tidligere udenrigsminister Jorge G. Castañeda søsatte ideen om, at der ikke var én, men to venstrebevægelser i Latinamerika. En god venstrefløj og en dårlig venstrefløj; det rigtige venstre contra det forkerte venstre; moderate contra ekstremister. Lula og Bachelet contra Chavez og Castro.

Problemet med den udlægning er, at så snart vi forsøger at skabe båse og hegne ind for at fremme forståelsen, så forsimpler og forvrænger vi også. Hvis man overhovedet kan indhegne forskellige venstreorienteringer i dagens Latinamerika, så kan man med større ret - som adjunkt Steen Fryba Christensen fra Aalborg Universitet har påpeget (CBS april 2006) - tale om tre slags venstrebevægelser og ikke to, fordi Cuba som regionens eneste diktatur klart adskiller sig fra resten af de latinamerikanske lande.

\section{Diktatorkassen}

Ved at proppe Venezuela og Cuba i samme boks opnår man at sidestille den demokratisk valgte præsident Chavez med diktatoren Castro. Og at de to jo beviseligt er slyngveninder gør blot sammenligningen endnu nemmere. Det virker logisk. Men derfra er der kun et kort skridt til at anvende betegnelsen diktator også om Hugo Chavez, sådan som en lang række massemedier efterhånden gør det pr. rygmarvsrefleks.

I øvrigt rubriceres Argentina og Bolivia også ofte sammen med Cuba og Venezuela, når tesen om de to typer venstreorientering i Latinamerika skal udlægges. Argentinas præsident, Nestór Kirchner, er røget i udbakken bl.a. fordi han tog et opgør med Den internationale Valutafond, IMF, om Argentinas økonomiske politik og forpligtelser oven på det argentinske sammenbrud i julen 2001. Bolivias præsident og indianske le- 
der, Evo Morales, har som erklæret socialist plejet nær politisk omgang med Castro og Chavez og værst: Morales har erklæret Bolivias naturressourcer for boliviansk ejendom og bedt internationale gasproducenter i Bolivia genforhandle deres kontrakter.

Men ved udelukkende at vurdere præsident Morales på det grundlag, tilsidesætter man en meget mærkbar og meget vigtig tendens i Latinamerika i disse år: de oprindelige indianske befolkningsgruppers voksende organisering og deres deraf følgende krav på indflydelse over jord, råstoffer, kultur mm. Evo Morales er indiansk leder lige så meget som han er præsident.

Det, som Castañeda kalder for 'det dårlige venstre' beskrives ofte med de populære negativbetegnelser: populisme og nationalisme. De nationalistiske tendenser, som tydeligvis præger nogle lande i regionen, hænger i det store og hele sammen med det gradvise opgør med USA's altafgørende indflydelse, som Latinamerika oplever i disse år.

Nationalisme er selvstændighedstrangens følgesvend. Vi behøver ikke gå længere end til Norge for at se, hvor svært det har været for nordmændene at vikle sig ud af flaget igen efter 1905. Ja, det er faktisk ikke en afsluttet proces endnu 100 år efter.

Førhen var Spanien kolonimagten i Latinamerika. Siden blev det USA, som de facto overtog den rolle bl.a. med præsident James Monroes doktrin fra 1823, hvor han fastslog at "de amerikanske kontinenter, der har tilkæmpet sig og hævdet frihed og uafhængighed, ikke ønsker, at nogen europæisk magt i fremtiden skal betragte dem som kolonisationsområder... Hvad der sker i denne hemisfære angår os ifølge sagens natur direkte og umiddelbart."

\section{Sovjets opløsning hjalp}

Doktrinen havde den effekt at USA nu havde de amerikanske kontinenter som deres eksklusive politiske område. Her herskede og her førte USA politik. Det vil også sige, at venstreorienterede regeringer i modsætning til det meste af resten af verden aldrig godvilligt fik en chance i Latinamerika; og opstod de en sjælden gang alligevel $-\mathrm{fx}$ ved opstand eller demokratiske valg - blev de knust.

Sovjetunionens sammenbrud og den Kolde Krigs ophør fjernede det brændemærke, som Latinamerikas venstrefløj havde båret rundt på. $\mathrm{Nu}$ kunne Washington ikke længere beskylde et hvilket som helst styre til venstre for midten for at være et brohoved for sovjetiske interesser i regionen. En formel, som USA havde anvendt tilbage fra 1954, hvor man med CIA's hjælp gennemførte et statskup og væltede Jacobo Arbenz' socialdemokratisk orienterede regering i Guatemala.

Med den Kolde Krigs ophør har latinamerikanske lande ikke længe- 
re været tvunget til at vælge mellem USA og Sovjetunionen. Det er én væsentlig årsag til, at venstredrejningen finder sted i Latinamerika. En anden væsentlig årsag er den voldsomme ulighed. Latinamerika er verdens mest skæve region, hvad velstand angår.

Ufattelig velstand og dermed magt koncentreret på relativt få hænder og en øresønderrivende fattigdom for resten. Hvis man kombinerer den ulighed med den øgede demokratisering, er resultatet logisk. Kombinationen af få magtfulde velhavere og mange fattige og underbemidlede vil naturligt føre til, at venstreorienterede ideer vinder frem.

\section{Venstresving uundgåeligt}

I Latinamerika var det nærmest uundgåeligt eftersom de økonomiske, sociale og politiske reformer, som blev gennemført samtidig med demokratiseringen i midten af 1980'erne ikke forbedrede vilkårene for de mange dårligt stillede, som tværtimod oftest fik det værre.

Den tendens havde i slutningen af 1990'erne gjort store grupper så lede ved udviklingen, at nogle ligefrem højlydt begyndte at sætte spørgsmålstegn ved demokratiets velsignelser. Meningsmålinger begyndte at reflektere utilfredshed med demokratiets muligheder. Man havde jo ikke sjældent haft det bedre under diverse diktatoriske regimer. Men i stedet for at søge tilbage til 'caudilloen', den stærke mand, så vælgerne til venstre.

Man kan sige, at venstrefløjens politikere på den måde blev demokratiets sidste halmstrå i en række latinamerikanske lande. Vælgernes sidste uprøvede mulighed - alle andre havde spillet fallit. På den baggrund kan bekymring over den aktuelle venstredrejning i Latinamerika, som man ser det udtrykt fra Washington, forekomme fejlplaceret, hvis ellers ønsket er at sikre en demokratisk udvikling.

Næppe en dag passerer uden fremtrædende advarsler om, at regionen - eller i hvert fald en del af den styrer mod populistisk undergang eller det, der er værre. Forandringerne i Latinamerika synes i høj grad at blive misforstået og desuden undervurderet.

USA's højrefløj inklusive Bush-administrationen ser fortsat udviklingen gennem et koldkrigs-prisme, hvor Castro-Chavez-Morales aksen angiveligt udgør en trussel mod USA. Påståede forbindelser til terrorisme eller narkotrafik hældes sommetider oveni. Dokumentation leveres ret beset aldrig. Som da USA's udenrigsministerium, State Department, uden yderligere forklaring sløjfede alt våbensalg til Venezuela i foråret 2006 på grund af manglende samarbejde i terrorbekæmpelse.

Selv mere liberale og moderate i USA er bekymrede over farerne, som de ser forbundet med 'Latinamerikas venstre-populistiske drej- 
ning'. Presse og medier er næsten entydigt præget af samme tema såvel i nyhedsdækningen som i kommentarer.

At der i virkeligheden er god grund til optimisme på netop den demokratiske udviklings vegne, bliver som regel overset eller forbigået. Demokrati har gradvist ikke bare vundet fodfæste, men slået rod. Det diskvalificerer ikke demokratiet som institution, at vælgerne i flere lande har formastet sig til at vælge venstreorienterede regeringer. Det underbygger ret beset demokratiet, at flere og flere lande søger større økonomisk og politisk uafhængighed og bredere handelssamkvem. En udvikling med større regional integration (eks. Mercosur) er i den sammenhæng logisk.

Når venstredrejningen i Latinamerika skal begrundes, bliver én af de allervæsentligste årsager ofte forbigået, nemlig at Latinamerika efter årene med militærdiktaturer og i takt med demokratiets fremmarch oplevede et sammenbrud i den økonomiske vækst.

\section{Katastrofe}

De seneste 25 år har reelt set været katastrofale for Latinamerika. Fra 1960 til 1980 øgedes per capita indkomsten i Latinamerika med 82 procent (renset for inflation). Fra 1980 til 2000 voksede den enkelte persons indkomst med ni (9) sølle procent! Og i de første fem år af dette nye århundrede (2000 til 2005) har væksten været på fire (4) procent samlet set.

Hvis man skal finde en vækstudvikling tilsvarende elendig i Latinamerika, skal man over 100 år tilbage og vælge en periode, som omfatter såvel den Første Verdenskrig som depressionen.

Latinamerika har som sagt den skæveste velstandsfordeling i verden, men uligheden er ikke blevet større i de seneste 25 år. Det er først og fremmest den manglende vækst, som har frarøvet halvanden generation muligheden for at forbedre levevilkårene. Mexico ville i dag have haft en gennemsnitlig levestandard som Spaniens, hvis økonomien havde fortsat sin vækst fra før 1980, og færre mexicanere ville være parate til at løbe risikoen ved illegal immigration til USA.

Det, vi er vidne til Latinamerika nu, er at USA mister indflydelse i det, der indtil for ganske nylig var USA's 'baggård'. Det er drastisk; det er gået stærkt, og det er efter alle solemærker at dømme uafvendeligt.

\section{Valutafonden svækket}

På ét område er Washingtons tab af indflydelse gået stort set upåagtet hen. Indtil for nylig havde Den Internationale Valutafond (IMF) mere eller mindre hånd i hanke med de fleste andre kreditkilder for udviklingslandenes regeringer. IMF var en slags 'gatekeeper'.

Hvis en regering ikke opnåede en aftale med IMF, ville den ikke kvalifi- 
cere sig til hovedparten af lån fra Verdensbanken, regionale banker som Den Interamerikanske Udviklingsbank, G7 regeringslån og nogle gange sågar heller ikke fra den private banksektor.

IMF har 184 medlemmer, men har altid været domineret af USA's finansministerium. Teknisk set kunne andre rige lande som de europæiske og Japan nedstemme USA (afstemning er proportionel efter et kvotesystem, som giver de rige lande et stort flertal), men det er praktisk talt aldrig sket i de seneste 62 år.

Långiverne med IMF har også haft afgørende indflydelse på udformningen af den såkaldte 'Washington Concensus', det sæt regler, som sigter på at begrænse statens regulering af markedet og åbne nationaløkonomierne for det internationale marked.

I dag er Washington Concensus et skældsord i det meste af Latinamerika. I årtier har der været en opfattelse af, at Washington kunne operere smertefrit igennem IMF, en tilsyneladende multilateral, teknokratisk institution, i forhold til landene i regionen. Det var gennem IMF, man pressede på for at overtale udviklingslande til at privatisere naturressourcer eller anvise vejen for en ansvarlig økonomisk politik. IMF var garanten for, at der blev ført en 'sund økonomisk politik'.

IMF's status har ændret sig betragteligt i de senere år, og er i nogle tilfælde blevet reduceret til en skygge af sig selv.

\section{Det argentinske eksempel}

Da Argentina i 2001 standsede betalingerne på en 100 milliarder dollar stor gæld, var det den største statskonkurs nogensinde i historien. Valuta og banksystemet brød sammen, og de fleste antog, at den argentinske regering var nødt til at opnå en ny aftale med valutafonden og modtage nye indskud for at få gang $\mathrm{i}$ $\emptyset$ konomien igen. Men der gik et år uden en aftale, og da den endelig kom i stand, var der ingen nye penge til Argentina. IMF tog faktisk fire milliarder dollar ud af landet i 2002.

Alligevel var den argentinske økonomi allerede i vækst efter tre måneder, og har siden sammen med Venezuela ligget med den højeste vækstrate på hele den vestlige halvkugle. Her fire år senere noterer Argentina fortsat vækst på 8-9 procent. Den argentinske præsident, Nestór Kirchner, som tog over i maj 2003, iværksatte en række tiltag stik imod IMF's krav, bl.a. en brysk forhandling om gælden, som fik de fleste kreditorer til at nedskrive deres tilgodehavender drastisk.

Den internationale erhvervspresse var fjendtlig over for Argentina, og IMF kørte sit tungeste skyts ind i det, der udviklede sig til en regulær styrkeprøve mellem IMF og Argentina. Argentinas regering ophørte sågar i september 2003 med at betale på sine lån hos IMF selv - et uhørt træk, som tidligere havde været forsøgt af paria-stater i mere eller mindre opløsning, som Congo og Irak. 
At misligholde sin gæld til valutafonden havde indtil da været lig med økonomisk isolation og nægtelse af eksportkreditter nødvendige for handel fx.

Argentina klarede sig igennem stort set ved egen hjælp, noget som efterfølgende betød at IMF mistede indflydelse og prestige i Latinamerika.

\section{Venezuelas oliepenge}

Samtidig havde en ny og anderledes långiver indfundet sig: Venezuela.

Da Argentina i december 2005 besluttede sig for at slå sig endegyldigt fri og sige farvel til IMF ved simpelthen at betale resten af sin gæld på 9,8 milliarder dollar tilbage på én gang (5,4 procent af Argentinas BNP), skød Venezuela 2,5 milliarder dollar i forehavendet med besked fra præsident Hugo Chavez om, at Venezuela var parat til at købe endnu flere argentinske statsobligationer, hvis der blev behov for det.

Umiddelbart forinden havde et andet land, Brasilien, sagt farvel til IMF og betalt hele sin gæld - én af de største i verden på 15,6 milliarder dollar tilbage til Valutafonden.

Venezuela tilbød i 2005 også Equador at købe for 300 millioner dollar i statspapirer, men det viste sig, at Equador kun havde brug for 25 millioner, som Venezuela så dækkede. Da Bolivia var ved at miste 170 millioner dollar i eksport af sojabønner til Colombia som følge af Colombias beslutning i april 2006 om at underskrive en bilateral handelsaftale med USA, trådte Venezuela til som ny køber.

Venezuela har blandt meget andet foreslået at oprette en 'Sydens Bank' til at finansiere udvikling i Latinamerika og har tilbudt at skyde fem milliarder dollar ind som startkapital. Venezuela sælger i forvejen billig olie i såvel Sydamerika som Karibien, hvor flertallet af små fattige østater nyder godt af Venezuelas PetroCaribe-program.

Set med Washingtons briller og udenrigspolitiske traditionalister tager Venezuelas handlinger sig ud som et forsøg på at opbygge en akse imod USA, og at Hugo Chavez har travlt med at købe sig til venskaber i Latinamerika. Chavez selv kalder det en bestræbelse på at om ikke frigøre så løsne USA's greb om regionen. Og han har ikke planer om at stoppe.

\section{USA mindre attraktiv}

Washington har forsøgt sig med en række bilaterale handelsaftaler (Chile, Colombia, Equador, Peru alle uden for Mercosurs inderkreds)

Der har været en betydelig interesse for disse aftaler, men også en erkendelse af, at USA ikke længere har helt så meget at tilbyde i disse handelsaftaler. Med mindre USA kan trække sig selv op ved håret og levere et fortsat hastigt voksende marked for latinamerikansk eksport trods et dundrende handelsunderskud. 
Og læg hertil, at Kina har meldt sig på banen med en styrke, som ikke kan undgå at svække USA's relative betydning i Latinamerika. Ud over kinesiske planer om at investere fem milliarder dollar i Venezuelas olieindustri, har Kina planer om investeringer for 20 milliarder dollar i sådan noget som jernbaner og anden infrastruktur. Ikke for Latinamerikas blå øjnes skyld. Kina er stærkt forhippet på at få del i Latinamerikas rige råstofressourcer, kobber, nikkel, olie samt soja, og det skal transporteres.

For Latinamerika ligger der en åbenlys risiko i at blive råstofleverandør endnu en gang - nu bare til Kina - uden at få del i udviklingen. Latinamerikanske lande går i stadig større grad ind og sikrer en grad af national kontrol over naturressourcerne. Det er sket i Venezuela med olien, i Bolivia med naturgas, i Equador med gas og olie, i Chile og Peru med kobber.

Rendyrket markedsøkonomi uden en aktiv rolle for staten er ikke længere i kridthuset i Latinamerika, hvor landene også har opdaget, hvor afgørende vækst er for fattigdomsreduktion.

\section{Større muskler}

Mange lande i regionen kan helt bogstaveligt mærke de nyfundne økonomiske og politiske muskler vokse. Det har givet sig adskillige politiske udtryk, som da USA's to nærmeste allierede i regionen, Chile og
Mexico, i FN's Sikkerhedsråd stemte imod USA's ønske om at få FN's opbakning til at invadere Irak.

I maj 2005 har USA for første gang i næsten 60 år måttet acceptere ikke at få sin foretrukne kandidat valgt som leder af Organisationen af Amerikanske Stater, OAS. I to omgange blev USA's kandidater afvist, og Chiles tidligere udenrigsminister José Miguel Insulza blev valgt promoveret af Brasilien, Argentina og Venezuela.

I juni samme år forsøgte USA at få OAS til at vedtaget en tilføjelse til organisationens charter om, at OAS skulle kunne vurdere og evaluere funktionen af de enkelte medlemslandes demokrati og intervenere, hvis man fandt, at demokratiet ikke fungerede. Alle forstod, at det var rettet imod Venezuela, hvis leder Hugo Chavez igen og igen peger på USA's ønske om at intervenere i hans land. USA's forslag faldt til jorden med et hult drøn.

Hugo Chavez er blevet USA's hovedfjende i en sådan grad, at selv Cuba fremstår mindre dæmonisk. Men ved at proppe Cuba og Venezuela i samme kasse, bliver det som allerede nævnt nemmere at erklære Chavez for diktator på linje med Castro.

Dæmoniseringen af Hugo Chavez foregår uophørligt, og presse og medier leverer unuanceret og ukritisk journalistik, hvor Chavez generelt beskrives som anti-demokrat, autoritær, diktator og en trussel mod regi- 
onen. Det sker som oftest uden eller med sparsom dokumentation.

\section{Aggressiv opposition}

I virkeligheden har intet land $\mathrm{i}$ Latinamerika så aggressiv en oppositionspresse som Venezuela under Hugo Chavez. Hovedparten af medierne ejes af oppositionsfolk, bl.a. nogle som deltog aktivt i kupforsøget mod Chavez i 2002. Den journalistik, som her præsteres, ville ikke få lov til at passere i de fleste vestlige lande. Deres redaktører og journalister ville ganske enkelt skulle forsvare sig i retten hver eneste dag.

Det gør ikke Hugo Chavez til verdens største demokrat, og hans facon bidrager heller ikke til, at man får det indtryk af den venezuelanske præsident. Men i det meste af resten af Latinamerika kan man godt skelne mellem Chavez' verbale udladninger og hans handlinger.

Her vækker det også mishag, når Chavez gumpetungt blander sig i deres landes anliggender med udmeldinger til fordel for den ene eller den anden kandidat i en valgkamp, som det skete senest i Peru. Men ingen eller kun meget få $\mathrm{i}$ Latinamerika køber Bush-administrationens udsagn om, at Chavez af den grund skulle være en destabiliserende faktor i regionen, en farlig indflydelse og en nationalistisk, populistisk, diktatorisk krigshetzer.

Og Washingtons forsøg på at isolere Venezuela i Latinamerika har ind- til videre kun bidraget til yderligere at isolere USA.

I december 2005 valgte Venezuelas opposition at boykotte parlamentsvalget, hvor man kunne have vundet omkring 30 procent af pladserne. Udeblivelsen fra valget skete med Washingtons velsignelse og har medført, at der nu tales om Venezuela som en et-parti-stat. Man skabte en Orwellsk virkelighed, og de internationale medier fortæller nu om den Chavez-kontrollerede nationalforsamling, men fortæller ikke at oppositionen imod OAS' og Europas opfordringer og uden gyldig grund nægtede at deltage i et demokratisk valg for bevidst at fremprovokere forestillingen om et ikke-demokratisk styre.

USA har siden hen blokeret for salg af militære reservedele til Venezuela, og tvunget Brasilien og Spanien til at annullere kontrakter på militærfly og patruljebåde til Venezuela med henvisning til, at de indeholdt teknologi fra USA. Hugo Chavez har søgt andre græsgange især Rusland - når det gælder våbenanskaffelse. Det har så kunnet udlægges som en del af det trusselsbillede, Chavez angiveligt udgør.

\section{Allende og Chavez}

De latinamerikanske lande opfatter det ikke sådan, hvilket bl.a. dokumenteres af Venezuelas optagelse i Mercosur her i 2006. Selv Chile, som ofte fremhæves af USA som et eksempel til efterfølgelse, og som var 
først i Sydamerika til at underskrive en bilateral handelsaftale med USA, vil ikke bakke op om USA's destabiliseringspolitik i forhold til Hugo Chavez.

Chile som i parentes har haft socialister i regeringen de seneste 17 år og haft en socialistisk ledet regering de seneste ni år. I Chile trækkes man fortsat med efterveerne af det militærdiktatur, som med USA's hjælp væltede den demokratisk valgte socialist, Salvador Allende, i 1973. Og mange chilenere mener, at de kan se en parallel.

Præsident Michelle Bachelet bad på et topmøde mellem EU, Latinamerika og Karibien i maj i år om at få skruet ned for koldkrigsretorikken i forhold til Chavez og Bolivias præsident Evo Morales.

I betragtning af, at Venezuela er USA's fjerdestørste olieleverandør, og at USA ikke kan undvære den venezuelanske olie, og Venezuela ikke kan undvære USA som aftager af olien og investor i olieindustrien, kan den ideologiske kamp mellem Bush-administrationen og Chavezregeringen forekomme mærkelig. Økonomisk og energimæssigt hænger USA og Venezuela uløseligt sammen.

Alligevel er der kun udsigt til, at de verbale udfald mellem Bush og Chavez fortsætter og forværres.

Chavez har ikke noget at tabe. Forsøgene på fra Washington at isolere og destabilisere ham vil fortsætte. Så Chavez vil næppe heller ændre spor
- slet ikke hvis han, hvad alt tyder på, får en komfortabel valgsejr ved præsidentvalget i begyndelsen af december i år.

Men flere års intensiv dæmonisering af Hugo Chavez fra Washington og mange internationale medier har sat sig sine spor, og Chavez trækkes frem som skrækeksempel i snart sagt enhver valgkamp i Latinamerika.

Det skete også i Mexico, hvor socialdemokraten, Andres Manuel Lopez Obrador, i annoncer og artikler og nyhedsudsendelser blev kaldt en mexicansk Hugo Chavez. Obrador blev i strid med sandheden beskyldt for at have modtaget penge fra Chavez til sin valgkampagne, og der blev spekuleret $i$, hvor vred USA ville blive, hvis mexicanerne valgte en person som Lopez Obrador, som straks ville kaste sig i armene på Castro og Chavez.

Det havde i høj grad sin virkning og blev muligvis afgørende for, at Loipez Obrador tabte med omkring en halv procent af stemmerne til den konservative Felípe Calderon. I Mexico lykkedes det for det siddende regeringsparti og de store erhvervsinteresser i nord at tage socialdemokraten Lopez Obrador fra kassen med moderate venstreorienterede og flytte ham over i kassen med 'diktatorer' og populister i løbet af valgkampen.

Spørgsmålet er, hvor længe Hugo Chavez vil kunne bruges som bussemand i valgkampe i Latinamerika. Chavez har efterhånden samlet sig 
et godt ry sammen blandt den brede vælgerskare på kontinentet som netop manden, der kan og vil tale de fattiges sag, og som i modsætning til andre, gør noget ved det både i regionen og hjemme i Venezuela, hvor sundheds- og alfabetiseringsprogrammer, jordreform og andet, som i langt højere grad ligner USA's egen New Deal-politik efter depressionen end et stalinistisk femårs-eksperiment, er med til at gøre ham populær.

\section{Et kludetæppe}

For nærværende kan 13 lande i Latinamerika klassificeres som værende til venstre for midten. Af disse er fire - Argentina, Bolivia, Ecuador og Paraguay ledet af partier, som ikke er med i nogen international venstreorienteret eller socialistisk bevægelse. Argentinas Kirchner siger ganske vist at hans regering er til venstre for midten, men hans Peronistparti har i de senere år defineret sig i retning af De kristelige Demokrater.

Paraguays regerende Coloradoparti har i det meste af sin levetid været drevet af en ekstrem højrepopulisme, bl.a. under general Stroessners diktatur.

Bolivias præsident Evo Morales' regeringsparti hedder Bevægelsen mod Socialisme, men fokuserer mere end noget på de oprindelige folks rettigheder og på Bolivias ret til sine egne naturressourcer.

Latinamerika er uden tvivl trådt mod venstre i de senere år, men der er ingen entydighed i den generelle orientering i politikken bortset fra det geopolitiske faktum, at de fleste sigter på større uafhængighed fra USA økonomisk og politisk. Lande som Brasilien og Venezuela fører energisk og aktivt en selvstændig udenrigspolitik. Chile har som det første land indgået en frihandelsaftale med Kina.

Det giver i virkeligheden ikke megen mening at bygge båse og tale om én-, to- eller flere former for venstreorientering i Latinamerika. Det er snarere et kludetæppe, hvor oprindelige folks rettigheder, orientering mod andre semiudviklede lande og meget andet er vævet ind. Hvis man absolut vil sætte de enkelte lande i bås, kan man lige så godt tale om de venstreorienterede, som vi kan lide og dem, vi ikke bryder os om. Faktum for dem alle er, at de - i modsætning til Cubas Fidel Castro - er demokratisk valgt.

Niels Lindvig er journalist ved DR's Orientering, $P 1$ 